\title{
Origins of...
}

\section{Cerebrospinal fluid analysis in clinical diagnosis}

\author{
A O Olukoga, J Bolodeoku, D Donaldson
}

Department of Clinical

Biochemistry, Hope

Hospital, Salford,

Manchester

A O Olukoga

\section{Nuffield Department of Pathology and Bacteriology, \\ University of Oxford, John Radcliffe Hospital, Headington, Oxford \\ J Bolodeoku}

Consultant Chemical Pathologist, East Surrey Hospital, Redhill, Surrey and Crawley Hospital, Crawley, West Sussex D Donaldson

Correspondence to: Dr A O Olukoga,

Department of Clinical Biochemistry, Hope Hospital, Eccles Old Road, Salford, Manchester M6 8 HD.

Accepted for publication 5 November 1996

\section{Introduction}

This article reviews important milestones in the evolution of the biochemical analysis of cerebrospinal fluid (CSF). Historically, knowledge of the biochemistry of CSF lagged far behind that of blood and urine, mainly because the fluid was much less readily accessible. However, by the time procurement of CSF by lumbar puncture became established as a routine clinical procedure, chemical methods for assaying a large number of analytes in blood had already been adequately established. Many of these methods were later adapted to CSF analysis and this, no doubt, facilitated more rapid development of the subject. Examination of CSF was, indeed, the first ancillary investigation to be introduced into the practice of clinical neurology and, for a considerable time, stood alone as a diagnostic aid to the physician.

It is most appropriate to regard the history of CSF as commencing with descriptive accounts of the meninges and the ventricles; these are the anatomical constraints of the space in which the fluid flows (fig 1).

The earliest of these accounts can be traced back to one of the Hippocratic writers (430-350 BC) who made reference to the falx cerebri. This was followed by descriptions of the meninges and ventricles-the lateral, third, and fourth - by the then two best known physicians of the city of Alexandria, namely Erasistratus (c 260 BC) and Herophilus (c 300 BC), but Rufus of Ephesus (AD c 98-117) also contributed some knowledge. Subsequently, Claudius Galen of Pergamum (AD 129-99) gave the first detailed account of the ventricular system; his work, however, was based on ox brain dissections. Nevertheless, there was to be a long wait until 1543 before a more accurate description of the system was provided by Andreas Vesalius (1514-64). Admittedly, Leonardo da Vinci (1452-1519) had produced a wax cast of the human ventricular system in about 1504, but his work was unknown and it had therefore been without influence until the 19 th century. Vesalius's account of the ventricular system was extended and improved upon by Giulio Aranzi (1530-89) in 1587; he provided a clearer description of the temporal horns of the lateral ventricles and of the choroid plexus. Moreover, he was the first to refer to the passage leading from the third to the fourth ventricle as an "aqueduct"; this passage was later named after François de le Boë Sylvius (1614-72) (fig 2). ${ }^{1}$
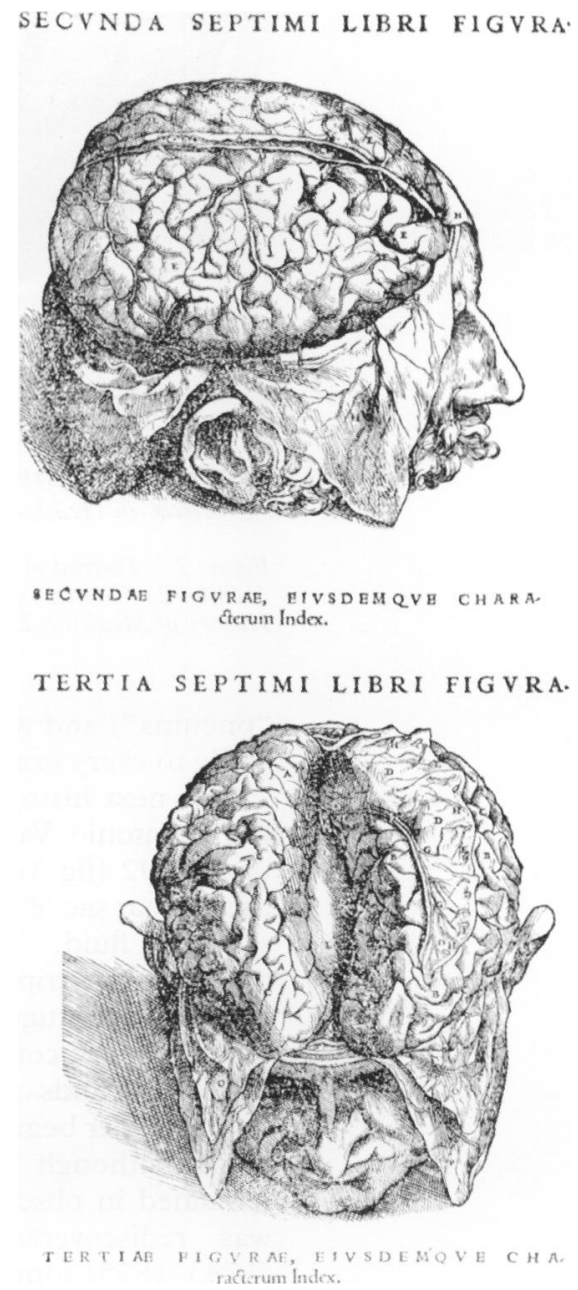

Figure 1 Portrait showing two views of the brains of dissected heads. Courtesy of the Wellcome Institute for the History of Medicine, London.

It was in the second century that Claudius Galen found there to be a clear fluid residue in the ventricles of the living brain. His work had been based on animal studies and he described the fluid as a vaporous humour produced by the brain - which he surmised provided energy for the whole body. This historical account comprised the first recognition of CSF. Moreover, this description of the fluid was an extension of the earlier concept of "vitalism", on which hinged the basic beliefs of Greek medicine of the time as to how the human body functioned. According to their views the heart produced a vital spirit which was the vaporous life determinant (referred to as psychic 


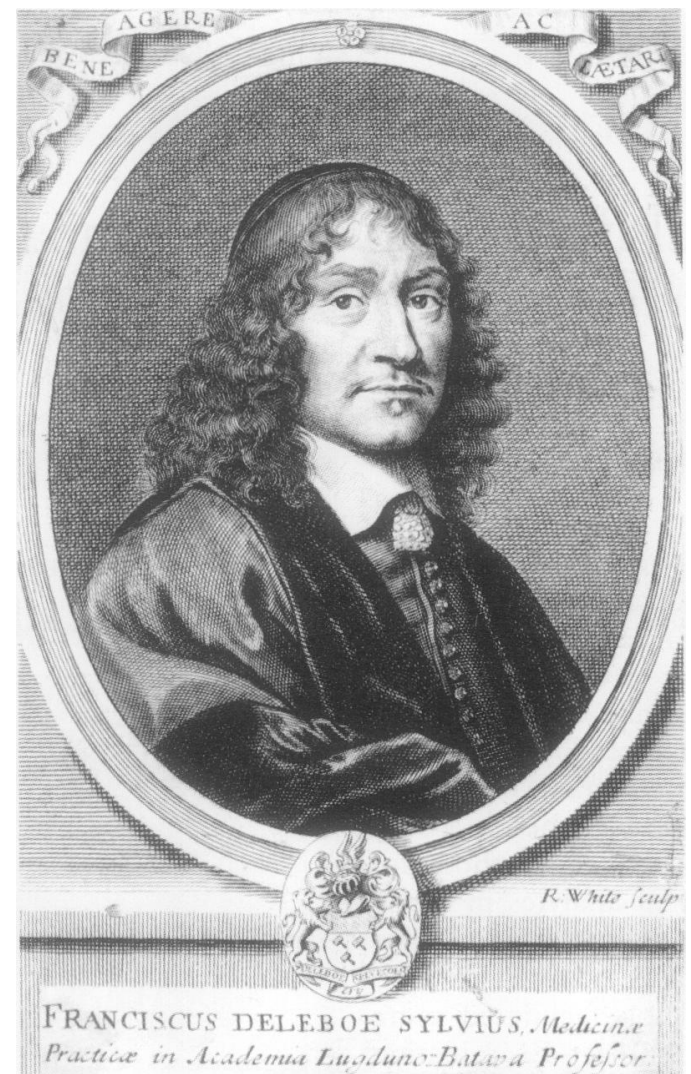

Figure 2 Portrait of François de le Boë Sylvius (1614-72). Courtesy of the Wellcome Institute for the History of Medicine, London.

"pneuma") and which was distributed peripherally to every organ in the body. ${ }^{2}$

The next historical reference to CSF came from Antonio Valsalva (1666-1723), but not until 1692 (fig 3); he drained clear fluid from the lumbar sac of the dog and compared it with synovial fluid. The first really clear and complete description of CSF was made by Domenico Cotugno (1736-1822) in $1764^{3}$; his recognition of continuity between the cerebral and spinal fluids can be regarded, in retrospect, as the proper beginning of modern CSF physiology, although this particular observation remained in obscurity for many years until it was rediscovered by François Magendie (1783-1855) some 60 years later (fig 4).

Prior to Magendie's descriptions of the normal presence of CSF in the brain and ventricles, in both 1825 and $1827,{ }^{45}$ any CSF found around the brain or within the ventricles at autopsy was regarded as being a consequence of disease.

Evidence that CSF was produced by the choroid plexus was provided in 1854 by $\mathrm{J}$ Faivre. ${ }^{6}$ In 1855 , Hubert von Luschka (182075 ) described the lateral recesses of the fourth ventricle through which CSF flowed into the subarachnoid space. These openings, which were subsequently named after him and called the "foramina of Luschka", establish communication between the ventricular and subarachnoid fluids in humans. ${ }^{7}$ The definitive demonstrations of CSF formation, its flow and its absorption were made in 1876 by Ernest Key (1832-1901) and Gustav Retzius (18421919). ${ }^{8}$

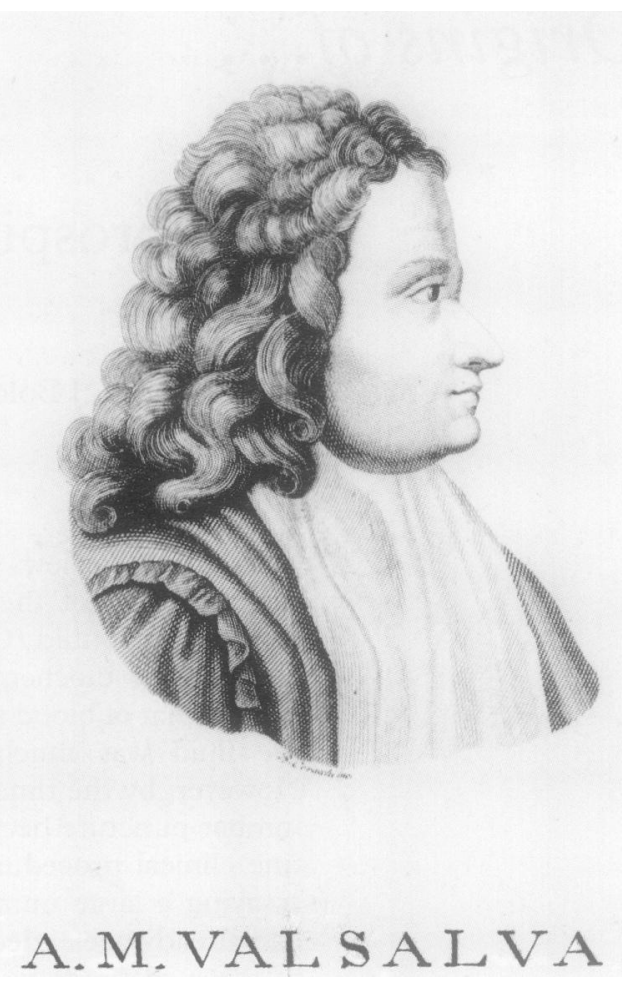

Figure 3 Portrait of Antonio Maria Valsalva (1666-1723). Courtesy of the Wellcome Institute for the History of Medicine, London.

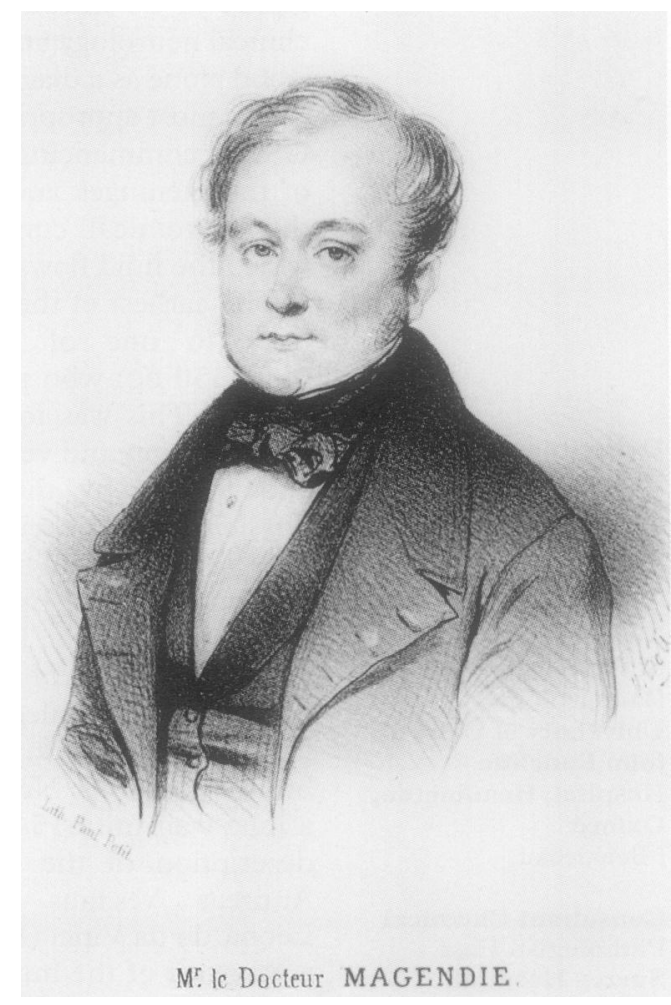

Figure 4 Portrait of François Magendie (1783-1855). Courtesy of the Wellcome Institute for the History of Medicine, London.

The formal examination of CSF started with development and perfection of the technique of lumbar puncture in 1891 by Heinrich Quinke (1842-1922) ${ }^{9}$; this was achieved while he was searching for a safe and simple way to remove the excess fluid in children with hydrocephalus. Quinke is credited as being the first to examine in detail the constituents of CSF. He counted 
the cells, measured total protein by the Kjeldahl method and identified the presence of bacteria in the fluid in pathological circumstances. However, it took another 20 years before the first comprehensive description of the chemical composition of CSF was made in 1911 by William Mestrezat (1883-1928). ${ }^{10}$ The earliest report of the diagnostic value of analysing CSF biochemically was made in 1893 by Ludwig Lichtheim (1845-1928) when he observed that glucose levels were low in both bacterial and tuberculous meningitis. ${ }^{11}$ Since that time glucose has been routinely measured in CSF

The bacteriological diagnosis of meningitis was made possible at this time because of progress that had been made previously in the field of microbiology. Such advances included the description of a technique for the staining of bacteria in 1875 by Carl Weigert (18451904). This was succeeded by a method for cultivating bacteria in 1877 , followed by a modification of it in 1881 in order to obtain pure cultures, both techniques having been developed by Robert Koch (1843-1910). Subsequently, Christian Hans Gram (b. 1853) published his now famous method for the differential staining of bacteria, the "Gram stain", in 1884. In the following year, the Ziehl-Neelsen stain for identifying the tubercle bacillus was described; it was based on the work of Franz Ziehl (1857-1926) and Freidrich Neelsen (1854-94). ${ }^{12}$ All these procedures were also applied to CSF. In 1906, August von Wasserman (1866-1925) applied his serological test, the "Wasserman reaction" (WR test), to CSF for the diagnosis of syphilis. ${ }^{13}$ This method was a modification of the complementfixation test which had been described earlier by Jules Bordet (1870-1961) in 1901 ${ }^{12}$; it had greatly facilitated the diagnosis of general paralysis of the insane (GPI, general paresis). Interestingly, in 1903, while working in Uganda, East Africa, Aldo Castellani (18771971) also found the trypanosome parasite, $T$ gambiense, in the CSF of patients suffering from sleeping sickness. ${ }^{14}$ Diagnostic cytology of CSF, other than routine total and differential cell counts, commenced with the recognition of neoplastic cells in 1904 by H Dufour ${ }^{15}$; routine examination of CSF for tumour cells was thereby firmly established in confirming disease of the central nervous system, especially when a cerebral tumour was suspected.

That the CSF occasionally contained yellow pigment was discovered soon after lumbar puncture had been adopted as a routine clinical procedure. This yellow discoloration was also observed in the supernatant CSF in cases of subarachnoid haemorrhage by Millian and Chiray in 1902 and they proposed the term "xanthochromia" to describe the phenomenon. ${ }^{16}$ In the following seven years, cases of xanthochromia, each being in association with a seemingly different aetiopathogenesis, were described. Georges Froin (1874-1903) in 1903 reported three clinical cases in which the CSF was not only yellow but also coagulatedand contained an abundance of lymphocytes; he associated this CSF "picture" (later to be termed "Froin's syndrome") with syphilitic meningitis. ${ }^{17}$ In 1910, Max Nonne (18611959) described six cases of spinal cord tumour, each having an increase in CSF globulin-but without lymphocytosis. This CSF picture was, thereafter, called "Nonne's compression syndrome"; another CSF pattern comprising an increase in protein, xanthochromia and spontaneous coagulation, was later termed the "Nonne-Froin syndrome". ${ }^{18}$ An insight into the mechanisms of xanthochromia was subsequently provided in 1936 by Robinson and Miller who produced experimental compression of the spinal cord in dogs and later recovered a xanthochromic high proteincontaining CSF ${ }^{19}$ Lawrence J Barrows et al established in 1955 that oxyhaemoglobin, bilirubin and methaemoglobin were pigments that could be detected in CSF in certain pathological conditions. ${ }^{20}$

The study of CSF proteins progressed in 1912 when Karl Friedrich Lange (b. 1883) demonstrated that the ability of certain pathological fluids to precipitate a gold sol could be used in the clinical diagnosis of general paresis. $^{21}$ This was the birth of the famous "colloidal gold test" which detected increases in the globulin content of CSF. The test was specific for CSF and had never been used on any other body fluid-including urine and blood. The original version of the test was improved upon in 1944 by reducing the $\mathrm{pH}$ of the chemical reaction, a modification that enhanced precipitation of the gold sol..$^{22}$ Although globulin precipitates colloidal gold, albumin has no such property. For the test, serial dilutions of CSF in saline were prepared in 10 test tubes (concentrations ranging from $1: 10$ to $1: 5120$ ) and left to stand overnight in the presence of cherry red colloidal gold solution. Numerical codes for the colour changes observed in pathological states were allocated as follows: no change 0 , a bluish tinge to the red 1 , a reddish tinge to the blue 2 , blue 3 , light blue supernatant with purple precipitation 4 , and a colourless supernatant with complete precipitation of the gold 5 . The colloidal gold test was used to study several neurological conditions; number sequences corresponded with specific diseases-for example, 0012344310 equated with a meningitic curve and was seen in syphilitic or bacterial meningitis. Likewise, 5555432100 equated with a paretic curve and was obtained mainly in general paresis, but sometimes was seen in tabes dorsalis and multiple sclerosis.

There were other qualitative methods for detecting excess globulin in CSF which were based on somewhat similar principles to that of the colloidal gold test, although they were less sensitive and less popular. These included Pandy's test in which globulins were precipitated by a saturated solution of carbolic acid, and the Nonne-Apelt reaction which used ammonium sulphate for globulin precipitation.

The next major landmark in CSF protein analysis was application of the electrophoretic methods developed by Hesselvik in 1939, thus enabling more detailed study of individual proteins. CSF electrophoresis was developed as a 
clinical tool in 1942 by Elvin Kabat (b. 1914) and associates who, on employing the Tiselius free boundary electrophoretic method, found increased concentrations of $\gamma$ globulin in the fluid of both neurosyphilis and multiple sclerosis patients. Moreover, they showed that these changes were independent of those in serum, suggesting that immunoglobulins were produced within the CNS in such diseases. ${ }^{23}$ In 1948, Kabat et al, for the first time, used an immunochemical (precipitin) method to quantify albumin and globulin in human CSF without prior concentration of the fluid. They established reference ranges for these analytes and confirmed the increase in $\gamma$ globulin fractions in multiple sclerosis. ${ }^{24}$ However, a severe limitation of the precipitin method actually used was that it required no less than 6-7 $\mathrm{ml}$ of CSF for duplicate albumin and $\gamma$ globulin estimations.

Measurement of CSF sugar and proteins had become established as being an important diagnostic aid by the first quarter of the 20th century. Biochemical developments in this area subsequently concentrated on further refining the analytical techniques and their applications to measuring CSF analytes. Examples included the practice of interpreting CSF sugar concentrations in relation to plasma values, which can be traced back to 1925 when George Goodwin and Harold Shelley established the dependence of the former on the latter. ${ }^{25}$ An important development in CSF glucose assay during the course of this century was the advent of the enzymatic glucose-oxidase and hexokinase methods. Hitherto, CSF glucose had been estimated principally by non-specific reducing methods, involving reduction of copper salts. Vincent Marks (b. 1930) studied glucose in CSF, blood, and urine in 1959; he compared lumbar and ventricular CSF glucose using the glucose-oxidase method in $1960 .^{26}$ In 1973 , K A Greenwald and associates used a hexokinase method for quantifying CSF glucose and they re-established the previously described relationship between CSF and serum glucose. ${ }^{27} \mathrm{~A}$ new methodology for protein included the turbidimetric estimation of CSF total protein using trichloracetic acid, which had been developed by William Mestrezat (1883-1928) in $1921 .{ }^{28} \mathrm{~F}$ P Kingsbury et al used sulphosalicylic acid instead of trichloracetic acid in a similar turbidimetric procedure in $1926 .{ }^{28}$ These were the forebears of the methods in common use today. A sensitive colorimetric method for CSF protein was also described by Howe Oliver Lowry in 1952 using the FolinCiocalteu reagent following treatment with an alkaline copper solution. ${ }^{29}$

The early 20th century also marked the advent of measurement of lactate in CSF as a potential disease marker. Lactate concentrations were first noted to be increased in the CSF from patients with tuberculous and bacterial meningitis in 1924 by Kikugoro Nishimura. ${ }^{30}$ However, in marked contrast to glucose, lactate has only recently been occasionally used as an early indicator of bacterial meningitis - as a differential aid in distinguishing this entity from aseptic meningitis.
Another diagnostic test applied to CSF and which was widely used during this period in the assessment of the blood-CSF barrier ("meningeal permeability"), was the "bromide test" described by Friedrich Walter in 1925 and $1929{ }^{31}$ Briefly, the patient takes bromide orally for several days; 24 hours after the last intake, blood and CSF are withdrawn and the ratio of the concentrations of bromide in plasma to that in CSF is determined; this was called the "permeability quotient". This quotient, which in normal individuals is three, was reported to be reduced in patients with meningitis and multiple sclerosis. ${ }^{32}$

The second half of the 20th century has witnessed even more rapid development in diagnostic CSF analysis. Quantitative measurements of CSF immunoglobulins were refined, using very precise methods and only requiring minute quantities of fluid; these remained useful in the diagnosis of multiple sclerosis until the early 1970s. The need to distinguish true intrathecal synthesis of immunoglobulins from increases in CSF protein concentrations due to leakage from plasma, as a consequence of impairment in the blood-CSF barrier, led to development of the "immunoglobulin index" in 1972 by B Delpech and E Lichtblau. ${ }^{33}$ This index relates concentrations of CSF immunoglobulins and albumin to the corresponding serum values. However, qualitative abnormalities in CSF immunoglobulins in the form of oligoclonal bands were also reported in patients with multiple sclerosis in 1959 by Ewald Frick, who used immunoelectophoresis, and in 1967 by Hans Link, using agar gel electrophoresis. ${ }^{35}$ The demonstration of oligoclonal bands in CSF by isoelectric focusing was first reported in 1972 by P Delmotte. ${ }^{36}$ Since then, routine detection of oligoclonal bands, by isoelectric focusing followed by immunofixation has supplanted quantitative CSF immunoglobulin measurements in the diagnosis of multiple sclerosis. Nevertheless, not all cases of CSF oligoclonal bands will turn out to be multiple sclerosis, as demonstrated in 1977 by K G Porter et al who reported oligoclonal bands in the CSF of patients with cryptococcal meningitis; these bands were shown to be antibodies to Cryptococcus neoformans. ${ }^{37}$ Inflammatory disorders of the CNS other than multiple sclerosis have also been shown to be associated with oligoclonal IgG bands. ${ }^{38}$ Extensive work was also undertaken with proteins which enabled further understanding of the blood-CSF barrier. These studies included application of specific protein measurements as markers of integrity of the blood-CSF barrier in different pathological states. ${ }^{39-42}$

Many more CSF analytes were evaluated as potential biochemical indicators of central nervous system diseases during this period. These have included biogenic amines (for Parkinson disease ${ }^{43}{ }^{44}$ ), enzymes (for infectious diseases and neoplasia ${ }^{45-48}$, C-reactive protein (for infectious diseases ${ }^{49}$ ), glutamine (for hepatic encephalopathy ${ }^{50}$ ), cytokines (for infectious diseases and multiple sclerosis $\left.{ }^{51}{ }^{52}\right), \beta_{2}$ microglobulin, ${ }^{53}$ neopterin, ${ }^{54}$ and myelin basic protein $^{556}$ (for acquired immunodeficiency 
syndrome dementia complex), amyloid precursor, $^{57}{ }^{58}$ and acetyl cholinesterase ${ }^{57}$ (for Alzheimer disease), and $\beta_{2}$ microglobulin, ${ }^{59}$ and neuron specific enolase ${ }^{60}$ (for neoplasia). Measurement of these analytes has been possible for some time but they have not yet achieved routine application. However, with further clinical evaluation in well controlled studies a few of them, such as $\beta_{2}$ microglobulin, neuron specific enolase, lactate dehydrogenase, and amyloid precursor, may yet have a role. ${ }^{61}$

Further applications of cytological methods to CSF examination include characterisation of $B$ and $T$ lymphocytes by cell surface antigen and rosetting techniques. These methods have been useful in evaluating immunological diseases of the CNS, such as multiple sclerosis; they have also enabled distinction between infectious meningitis (in which $\mathrm{T}$ cells predominate) and lymphomatous meningitis in patients with lymphomas or leukaemia (in which B cells predominate).$^{62-64}$ However, they are now seldom required for routine diagnosis. Rapid diagnosis of viral encephalitis by specific immunofluorescent staining of CSF cells was also reported in $1973 .{ }^{65}$ Advances in the microbiology of CSF have included newer tests based on immunological methods or gene amplication techniques; these hold great promise for the diagnosis of infections caused by organisms that are difficult to culture or which are present in only very small numbers. ${ }^{66}$

\section{Conclusions}

The origins of knowledge relating to the analysis of CSF, together with its diagnostic applications, have been chronicled in this brief review. We have learned that the history of CSF in clinical diagnosis has lagged somewhat behind that of urine and blood. Development of the lumbar puncture as a routine clinical procedure for obtaining CSF facilitated rapid growth in the formal examination of this fluid. Furthermore, the analytical techniques and instrumentation, which had been designed for blood analysis, were then adapted to studying CSF. This enabled intensive investigation of the fluid and, consequently, a fairly large body of information on the subject now exists. New CSF analytes continue to emerge as potential markers of CNS disease although many of them have yet to be accepted as routine procedures.

1 Clarke E, O'Malley CD. The ventricular system and CSF. In: The human brain and spinal cord. 1st ed. Berkeley, Los In: The human brain and spinal cord. 1st ed. Berkeley,

2 Torack RM. Historical aspects of normal and abnormal brain fluids: I. Cerebrospinal fluid. Arch Neurol 1982;39: 197-201.

3 Viets H. Domenico Cotugno: His description of the cerebrospinal fluid. Bull Inst Hist Med 1935;3:701-38.

4 Magendie F. Treatise on a liquid that is found within the cranium and the spinal canal of man and mammals. $\mathcal{f}$ Physiol Exp Pathol 1825;5:27-37.

5 Magendie F. Further notes on the cerebrospinal fluid. $f$ Physiol Exp Pathol 1827;7:5-27,66-82.

6 Faivre J. Recherches sur la structure du conarium et des plexus choroides chez l'homme et les animaux. Gaz Med Paris 1854;9:555.

7 Von Luschka H. Die Adergeflechte des menschlichen Gehirns. Leipzig, G Reimer, 1855 . cited by Torack RM. Historical aspects of normal and abnormal brain fluids: $I$. Cerebrospinal fluid. Arch Neurol 1982;39: 197-201.

8 Key A, Retzius G. Studien in der Anatomie des Nervensystems und des Bindgewebes. Stockholm: Samson and Wallin, 1876.
9 Quinke HJ. Die Lumbalpunction des Hydrocephalus. Berl Klin Wochenschr 1891;28:929-65.

10 Mestrezat W. Le liquide céphalo-rachidien normal et pathologique, valeur clinique de l'examen chimique. Thèse No.17, 1911 .

11 Lichtheim L. Re: The proposal of Quincke to withdraw cerebrospinal fluid by lumbar puncture in cases of brain disease. Dtsch Med Wochenschr 1893;19:1234.

12 Bulloch W. The history of bacteriology. 1st ed. London: Oxford University Press, 1938.

13 Von Wassermann A, Plaut F. Ueber das Vorhandensein Syphilitischer Antistoffe in der Cerebrospinal flüssigkeit von Paralytikern. Dtsch Med Wochenschr 1906;32:1769-72.

14 Castellani A. On the discovery of a species of trypanosoma in the cerebrospinal fluid of cases of sleeping sickness. Proc $R$ Soc 1903;71:501-8.

15 Marks V, Marrack D. Tumour cells in the cerebrospinal fluid. F Neurol Neurosurg Psychiatry 1960;23:194-201.

16 Millian G, Chiray. Méningite à pneumocoques. Xanthochromie du liquide céphalo-rachidien. Bull Soc Anat Pari $1902 ; 4: 550-2$.

17 Froin G. Inflammations meningées avec réactions chromatique, fibrineuse et cytologique du liquid céphalorachidien. Gaz Hôp Paris 1903;76:1005-6.

18 Nonne $M$. Ueber das Vorkommen von starker phase-1reaction bei fehlender lymphocytose bei 6 Fällen von Rückenmarkstumor. Deutsche Ztschr $f$ Nervenh, Leipz 1910 40:161-7.

19 Robinson FH, Miller BN. On differentiation of coloured cerebrospinal fluids. Am $\mathscr{f}$ Med Sci 1936;191:538-42.

20 Barrows LJ, Hunter FT, Banker BQ. The nature and clinical significance of pigments in the cerebrospinal fluid. Brain 1955;78:59-81.

21 Lange C. Die Ausflockung Kolloidalen Goldes durch Zerebrospinalflussigheit bei luetischen Affektionen des zentranervensystems. $Z$ Chemother 1912;1:44-78.

22 Lange $\mathrm{C}$, Harris $\mathrm{AH}$. The significance of the $\mathrm{pH}$ in the colloidal gold reaction. F Lab Clin Med 1944;29:970.

23 Kabat EA, Moore DH, Landow H. An electrophoretical study of the protein components in cerebrospinal fluid and their relationships to the serum proteins. $f$ Clin Invest their relationsh

24 Kabat EA, Glusman M, Knaub V. Quantitative estimation of the albumin and gamma globulin in normal and pathologic cerebrospinal fluid by immunochemical methods. $\mathrm{Am}$ f Med 1948;4:653-62.

25 Goodwin GM, Shelley HJ. The sugar content of the cerebrospinal fluid and its relation to the blood sugar. Arch Intern Med 1925;35:242-58.

26 Marks V. True glucose content of lumbar and ventricular cerebrospinal fluid. 7 Clin Pathol 1960;13:82-4.

27 Greenwald KA, Speicher CE, Evers W, Henry JB. Glucose content in cerebrospinal fluid: A comparison with glucose levels in serum as determined by copper reduction and hexokinase methods. Am $\mathcal{F}$ Clin Path 1973;59:518-20.

28 Peters T Jr, Biamonte GT, Doumas BT. Protein (total protein) in serum, urine and cerebrospinal fluid; albumin in serum. In: Faulkner WR, Meites S, eds. Selected methods of clinical chemistry. Washington, DC: American Association for Clinical Chemistry, 1982.

29 Daughday WH, Lowry OH, Rosebrough NJ, Fields WS Determination of cerebrospinal fluid protein with the Folin phenolic reagent. f Lab Clin Med 1952;39:663.

30 Nishimura $K$. The lactic acid content of blood and spinal fluid. Proc Soc Exp Biol Med 1924;22:322-4

31 Davson H. Blood-brain and blood-CSF barriers. In: Physiology of the cerebrospinal fluid. 1 st ed. London: Churchill Ltd, 1967:296-8.

32 Haerer AF, Tourtelotte W, Richard KA, Gustafson GM Byran ER. A study of the blood-CSF-brain barrier in multiple sclerosis. I. Blood-CSF barrier to $\mathrm{NaBr}$. Neurology 1964;14:345-54.

33 Delpech B, Lichtblau E. Etude quantitative des immunoglobulines $\mathrm{G}$ et de l'albumine du liquide cephalorachidien. Clin Chim Acta 1972;37:15-23.

34 Frick E. Immunophoretische Untersuchungen am Liquor cerebrospinalis. Klin Wochenschr 1959;37:645-51.

35 Link H. Immunoglobulin G and low molecular weight proteins in human cerebrospinal fluid: chemical and immunoogical characterisation with special reference to multiple sclerosis. Acta Neurol Scand 1967;43(Suppl 28): 1-136.

36 Delmotte P. Resultats comparatifs de l'electrophorese en agar et de l'examen par electrofocalisation des gammaglobulines du liquide cephalorachidien. Acta Neurol Belg 1972; 72:226-34.

37 Porter KG, Sinnamon DG, Gillies RR. Cryptococcus neoformans-specific oligoclonal immunoglobulins in cerneoformans-specific oligoclonal immunoglobulins in cerebrospinal

38 Thompson EJ, Keir G. Laboratory investigation of cerebrospinal fluid proteins. Ann Clin Biochem 1990;27:425-35.

9 Felgenhauer K, Schliep G, Rapic N. Evaluation of th blood-CSF barrier by protein gradients and the humoral immune response within the central nervous system. $f$ Neurol Sci 1976;30:113-28.

40 Schliep G, Felgenhauer K. The alpha-2-macroglobulin leve in CSF: a parameter for the condition of the blood-CSF barrier. $f$ Neurol 1974;207:171-81.

41 Keir G, Thompson EJ. Proteins as parameters in the discrimination between different blood-CSF barriers. $尹$ Neurol Sci 1986;75:245-53.

42 Thompson EJ. The CSF proteins: $A$ biochemical approach. Amsterdam: Elsevier, 1988. 
43 Bernheimer H, Birkmayer W, Hornykiewicz O. Homovanillic acid in the cerebrospinal fluid in Parkinson's syndrom and other diseases of the CNS. Wien Klin Wochenschr 1966; 23:417-19

44 Wood JH. Neurobiology of cerebrospinal fluid. I. New York Plenum, 1980

45 Wroblewski F, Decker B, Wroblewski R. Activity of lactate dehydrogenase in spinal fluid. Am f Clin Pathol 1957;28. 269-71.

46 Chatterley S, Sun T, Lien Y. Diagnostic value of lactate dehydrogenase isoenzymes in cerebrospinal fluid. $\mathcal{F}$ Clin Lab Anal 1991;5:168-74.

47 Bach F, Bach FW, Pedersen AG, Larsen PM, Dombernowsky $P$. Creatine kinase-BB in the cerebrospinal fluid as a marker of CNS metastases and leptomeningeal carcinomatosis in patients with breast cancer. Eur $\mathcal{F}$ Cancer Onco 1989;25:1703-9.

48 Lampl Y, Paniri Y, Eshel Y, Sarova-Pinchas I. Alkaline phosphatase level in CSF in various brain tumours and pulmonary carcinomatous meningitis. F Neurooncol 1990;9:3540.

49 BenGershom E, Briggeman-Mol GJ, de Zegher F. Cerebrospinal fluid C-reactive protein in meningitis: diagnostic value and pathophysiology. Eur 7 Paediatr 1986;145:246-9

50 Hourani BT, Hamlin EM, Reynolds TB. Cerebrospinal fluid glutamine as a measure of hepatic encephalopathy. fluid glutamine as a measure of

51 Lopez-Cortes LF, Cruz-Ruiz M, Gomez-Mateos J, JimenezHernandez D, Palomino J, Jimenez E. Measurement of lev els of tumour necrosis factor-alpha and interleukin-1-bet in the CSF of patients with meningitis of differen aetiologies: utility in the differential diagnosis. Clin Infect Dis 1993;16:534-9.

52 Maimone D, Gregory S, Arnason BG, Reder AT. Cytokine levels in the cerebrospinal fluid and serum of patients with multiple sclerosis. 7 Neuroimmunol 1991;32:67-74.

53 McArthur JC, Nance-Sproson TE, Griffin DE, Hoover D, Selnes OA, Miller EN, et al. The diagnostic utility of elevation in cerebrospinal fluid beta 2-microglobulin in HIV-1 tion in cerebrospinal fluid beta 2-microg

54 Griffin DE, McArthur JC, Cornblath DR. Neopterin and interferon-gamma in serum and cerebrospinal fluid of patients with HIV-a
$1991 ; 41: 69-74$.
55 Whitaker JN, Lisak RP, Bashir RM, Fitch OH, Seyer JM, Krance $\mathrm{R}$, et al. Immunoreactive myelin basic protein in the cerebrospinal fluid in neurological disorders. Ann Neurol 1980;7:58-64.

56 Liuzzi GM, Mastroianni CM, Vullo V, Jirillo E, Delia S, Riccio P. Cerebrospinal fluid myelin basic protein as predictive marker of demyelination in AIDS dementia complex. F Neuroimmunol 1992;36:251-4.

57 van Gool WA, Bolhuis PA. Cerebrospinal fluid markers of Alzheimer's disease. F Am Geriatr Soc 1991;39:1025-39.

58 Farlow M, Ghetti B, Benson MD, Farrow JS, van Nostrand WE, Wagner SL. Low cerebrospinal fluid concentrations of soluble amyloid beta-protein precursor in hereditary soluble amyloid beta-protein precursor in
Alzheimer's disease. Lancet 1992;340:453-4.

59 Adachi N. Beta-2-microglobulin levels in the cerebrospinal fluid: their value as a disease marker. A review of the recent literature. Eur Neurol 1991;31:181-5.

60 Beelen NAA, Twijnstra A, van de Pol M, Menheere PPCA. Neuron-specific enolase in cerebrospinal fluid of patients with metastatic and non-metastatic neurological disease. Eur f Cancer 1993;29A: 193-5.

61 Watson AM, Scott GM. Clinical utility of biochemical analysis of cerebrospinal fluid. Clin Chem 1995;41:343-60.

62 Kam-Hausen S, Frydén A, Link H. B and T lymphocytes in cerebrospinal fluid and blood in multiple sclerosis, optic neuritis and mumps meningitis. Acta Neurol Scand 1978;58:95-103

63 Davies SF, Gormus BJ, Yarchoan R, Kaplan ME. Cryptococcal meningitis with false-positive cytology in the cerebrospinal fluid: use of T-cell rosetting to exclude meningeal lymphoma. $7 A M A$ 1978;239:2369-78.

64 Goodson JD, Strauss GM. Diagnosis of lymphomatous leptomeningitis by cerebrospinal fluid lymphocyte cell surface markers. Am F Med 1979;66:1057-9.

65 Dayan AD, Stokes MI. Rapid diagnosis of encephalitis by immunofluorescent examination of cerebrospinal fluid cells. Lancet 1973;i:177-9.

66 Balows A, Hausler Jr. WJ, Herrmann KL, Isenberg HD, Shadomy HJ, editors. Manual of clinical microbiology: Diagnostic technologies in clinical microbiology. 5th ed. Washing ton, DC: American Society of Microbiology, 1991:119-27. 